Deividas Šlekys*

Vilniaus universiteto Tarptautiniu santykiu ir politikos mokslu institutas

\title{
Amerikietiškosios kariavimo tradicijos svarba ir keliamos problemos
}

\begin{abstract}
Šiame straipsnyje aptariama amerikietiškosios kariavimo tradicijos (ang. American Way of War) koncepcija, jos specifika ir pagrindiniai bruožai. Pirmoje teksto dalyje bandoma išsiaiškinti, kaip tam tikri požiūriai, idèjos suformavo specifinį amerikiečių požiūrị i karą, ir kokias tai turëjo bei iki šiol turi pasekmes praktinei JAV užsienio ir gynybos politikai. Antroje dalyje trumpai apžvelgiama šios tradicijos įtaką NATO transformacijos raidai. O trečiojoje bandoma pasiaiškinti, ar visa tai turi arba gali turèti kokị nors poveikị Lietuvos gynybos politikai bei karybai.
\end{abstract}

\section{Ivadas}

Aktyvus dalyvavimas įvairiose misijose, narystė NATO, tebesitęsianti gynybos reforma Lietuvą vis labiau įtraukia į sūkurị, kuriame sukasi visos Vakaru valstybės. Pamažu ir Lietuvoje pradedama kalbèti apie transformacija, naujas karines technologijas (pvz., nepilotuojamus orlaivius (ang. - UAV)), naujas karines doktrinas bei taktikas ${ }^{1}$. Tokių diskusijų atsiradimą bei sprendimus, kurie po jų būna priimami, reikia vertinti teigiamai. Lietuva, būdama jauna valstybė, atgavus nepriklausomybę, kariuomenę ir krašto apsaugos sistemą kūrè po Šaltojo karo: kaip i̇manoma didesnẻ kariuomenė, koncentruojamasi ties teritorinès gynybos idejja ir kt. Tačiau Vakarų valstybès kaip tik buvo pradejjusios atsisakyti tokio tipo kariuomenių. Nors nevienodu tempu, tačiau jos pamažu pereidinejo prie mažesnių, profesionalių kariuomenių. Pradèjo vyrauti nuostata, jog tokio tipo, kokybiškai parengtos, kariuomenės gali atlikti savo misiją geriau nei kiekybiškai didesnès karinès pajègos. Lietuvoje į šiuos pokyčius karyboje rimčiau pradèta žiūrèti tik tada, kai stojimo į NATO kontekste

\footnotetext{
* Deividas Šlekys - Vilniaus universiteto Tarptautinių santykių ir politikos mokslu instituto doktorantas. Adresas: Vokiečiu g. 10, 01130 Vilnius, tel. 85 2514130, el. paštas - deividas.slekys@ tspmi.vu.lt

Kalbėdami apie „transformaciją“" gynybos, saugumo ekspertai bei politikai turi omenyje valstybiu kariuomenių reformas, kurios buvo inicijuotos ir pradètos dèl pokyčių karinių technologijų srityje, geopolitinejje sanklodoje ir kt. Pirmieji "transformacijos“ sąvoką pradejjo naudoti amerikiečiai. Ilgainiui ši sąvoka tapo labai madinga, nes nuolatinis jos minëjimas tarsi leidžia pabrèžti, jog valstybės seka tendencijas gynybos politikoje ir karyboje. Dabar kone kiekviena Vakarų valstybė, kalbèdama apie gynybos reformas, akcentuoja žodį "transformacija“, tuo tarsi pabrèždama vykdomų pokyčių krypti, naujumą ir svarbumą.
} 
tapo aišku, jog reformos yra būtinos, norint sẻkmingai įsijungti i Aljanso veiklą. Pamažu Vakaruose vykstančios akademinès, politinès diskusijos apie ateities grèsmę, naujo tipo kariuomenę, ginklus, doktriną pradejjo dominti ir mūsų kariškius, civilius tarnautojus, politikus. Tačiau šis naujovių įsisavinimo ar bandymų tai padaryti procesas yra labai ilgas procesas, turintis nemažai trūkumų.

Tai, kad yra bandymu, méginimų sekti naujausias karybos madas, tikrai yra sveikintinas dalykas. Tačiau šioje vietoje norisi kelti klausimą, ar iki galo yra suvokiama, kodèl vienos ar kitos idejos, technologijos, doktrinos yra vyraujančios, o kitos nèra. Nemenkinant kariškių bei civilių dirbančių KAS nuopelnų bei sugebëjimų reikia pastebėti, jog Lietuvoje dar nèra susiformavusi tradicija kritiškai įvertinti ir bandyti suprasti karyboje ir gynybos politikoje vykstančius procesus ${ }^{2}$. Daugeliu atveju yra daroma ir veikiama todèl, jog taip daro ar liepia NATO, JAV, kitos valstybės. Tačiau gal tai, kas tinka Jungtinėms Valstijoms, ar Švedijai, netinka Lietuvai ir pan. Tik suvokdami, kodèl karybos madas diktuojančios Jungtinès Valstijos vykdo vienokią ar kitokią gynybos politika, kodèl jos pasirinkta karinės reformos kryptis yra būtent tokia, galésime suvokti ir suprasti kas tinka ir kas netinka Lietuvai.

\section{Amerikietiškoji kariavimo tradicija}

Jungtinès Valstijos, neginčijamai būdamos galingiausia karine jèga pasaulyje, diktuoja madas karyboje. Visos valstybès viena ar kita forma bando kopijuoti JAV karinėje srityje. Pažvelgę i i istoriją galime aptikti ne vieną panašų pavyzdị: XVII a. visi kopijavo švedus ir prancūzus, XIX a. pr. - Napoleono kariuomenès modeli, po $1871 \mathrm{~m}$. - Vokietijos ir pan. Kadangi daugeliu atveju būdavo kopijuojamos karinès technologijos ar naujos karinès formuotès, tai procesas ilgai neužtrukdavo. Tačiau reikia pastebèti, jog techninius dalykus nukopijuoti lengva, tačiau taip vadinamają naujuju pokyčių „dvasią“ ar reikalingas sąlygas - ne visada. Kiekviena didžioji karinè galia turëjo ir iki šiol turi savo savitą, specifinę karinę tradiciją, kariavimo būdus ${ }^{3}$.

\footnotetext{
${ }^{2}$ Lietuvoje karyba ir su ja susijusiomis sritimis (saugumo studijomis, karo sociologija, terorizmo studijos karo teorija ir $t$.t.) domisi ir tyrimus atlieka gana mažai ekspertu ir mokslininkų: T. Jermalavičius, J. Novagrockienė, K. Paulauskas, E. Račius, M. Šešelgytė, V. Urbelis ir keletas kitu. Karybos tematika mažai rašo ir šalies karininkai, o iš jų būtų galima išskirti plk. G. Zenkevičių.

${ }^{3}$ Plačiąja prasme teoretikai kalba apie vakarietišką kariavimo tradicija (ang. western way of war), kuri pasižymi tuo, jog skiria dideli dèmesį ịvairioms technologijoms, disciplinai ir kt. Taip yra skiriami britiškasis, vokiškasis ir kt. kariavimo būdai. Karo istorikai ir ekspertai iki šiol ginčijasi dèl britiškosios kariavimo tradicijos, tačiau pamažu sutariama, jog jos skiriamieji bruožai yra kombinacija ekonominio spaudimo, blokados, jungtinių operaciju jūroje ir sausumoje bei patirties, igytos, išlaikant Britu imperijos kolonijas. Tuo metu vokiškosios kariavimo tradicijos skiriamaisiais bruožais yra laikomi siekiai karą padaryti kaip i̇manomą trumpa, įveikiant priešą mūšyje pasinaudoti siurprizu, ir apeinamaisiais manevrais. French D., The British way in warfare 1688-2000, London: Unwin Hyman, 1990; Howard M., ,"The British Way in Warfare: A Reappraisal“ , Howard M., sudar., The causes of wars and other essays, Cambridge, Mass.: Harvard University Press, 1983; Strachan H., „The British Way in Warfare", Chandler D., sudar., The Oxford history of the British Army, Oxford: Oxford University Press, 1996; Citino R. M., The German way of war: from the Thirty Years' War to the Third Reich, Lawrence: University Press of Kansas, 2005.
} 


\subsection{R. F. Weigley koncepcija}

Ne išimtis ir Jungtinès Valstijos. Mokslininkai, kariškiai nenuilsdami ginčijasi dèl to, ką reikètų laikyti išskirtiniais amerikiečių kariavimo bruožais (ang. - american way of war). Tačiau jie visi sutinka su tuo, kad tokia tradicija egzistuoja, ir kad ji darè i̇taką amerikiečių kariavimui nuo pat valstybés susikūrimo. Ši įtaka išliko iki šių dienu, tačiau kaip tik šios amerikietiškosios kariavimo tradicijos įtakos kitų valstybių ar karinių aljansų karybai svarba yra mažai tyrinejjama.

Oficialiu „,amerikietiškosios kariavimo tradicijos“ koncepcijos autoriumi yra laikomas įtakingas amerikiečiu karo istorikas Russelas F. Weigley. Knygoje „The American Way of War: a History of United States Military Strategy and Policy" jis suformuluoja ir pateikia pagrindinius amerikiečių karybos specifinius bruožus ir aspektus ${ }^{4}$.

Atlikdamas savo istorinị tyrimą ir tikrindamas savo hipotezes, Weigley rèmėsi kito karo istorijos klasiko Hanso Delbrücko idejomis. Šis, XIX a. pab. - XX a. pr. gyvenęs vokiečių istorikas, aprašęs karybos istoriją nuo seniausių laiku iki Napoleonu karu, prièjo prie išvados, jog per visus laikotarpius egzistavo dviejų tipų karyba. Jo teigimu, „pirmas, visų strategiju principas iš esmės yra sušaukti kariuomenę, surasti pagrindinę priešininko kariuomenę, nugalèti ją ir persekioti priešą tol, kol jis sutiks pasiduoti, sudaryti taiką “5. Ši kariavimo būdą jis pavadino „sunaikinimo strategija“ (ang. strategy of annihilation). Pagrindinis šios strategijos tikslas - mūšis, kuriame siekiama visiško priešo sunaikinimo.

Tačiau Delbrücko atlikti istoriniai tyrimai parodè, jog karuose ne visada būdavo siekiama mūšio, ir kad jie vykdavo visai kitaip. Todèl jis teigè, jog egzistuoja ir kitoks kariavimo būdas - "varginimo strategija“ (ang. strategy of attrition/exhaustion) ${ }^{6}$. Tai toks kariavimo būdas, kai priešas nuolat yra varginamas: naikinamos jo maisto, amunicijos atsargos, griaunamos logistikos ir komunikacijos linijos, užpuolami atsilikę kariniai daliniai ${ }^{7}$. Tačiau būtina pastebèti, jog antroji varginimo strategija, anot Delbrücko, nèra pirmosios strategijos tam tikra variacija ar už ją žemesnè. Abi strategijos yra lygiavertès ${ }^{8}$.

Weigley, atlikdamas JAV karybos istorijos tyrimą, visą jos raidą interpretavo per šių dviejų skirtingų kariavimų strategijų prizmę. Jis paprasčiausiai žiūrèjo, kuri strategija buvo dažniau taikoma. Jo atsakymas yra gana griežtas

\footnotetext{
${ }^{4}$ Weigley, R. F., The American way of war: a history of United States military strategy and policy, New York: Macmillan, 1973.

${ }^{5}$ Delbrück H., History of the Art of War, vol. 4, vert. Renfroe W. J., Lincoln: University of Nebraska Press, 1990, p. 293.

${ }^{6}$ Ten pat, p. 294.

${ }^{7}$ Klasikinis pavyzdys būtų Napoleono žygis ị Rusiją 1812 m., kai rusai kaip įmanydami vengè mūšio ir visais įmanomais būdais vargino prancūzų kariuomenę.

${ }^{8}$ Craig G. A., „Delbrück: The Military Historian“, Paret P., sudar., Makers of modern strategy from Machiavelli to the nuclear age, Oxford : Clarendon, 1984, p. 342.
} 
ir vienareikšmis - JAV kariavimo tradicija yra paremta sunaikinimo strategija. Savo knygoje jis teigia, kad „pačioje pradžioje (JAV nepriklausomybès karo metu - D. S.), kai Amerikos kariniai resursai buvo menki, buvo imtasi vilti teikiančių sprendimu, nes buvo taikoma varginimo strategija; tačiau valstybès turtams didejant [...] pamažu įsivyravo sunaikinimo strategija, kuri ir tapo amerikiečiu kariavimo tradicija"9 . Vèliau Weigley išsakè savo abejones dèl to, kad įvairią ir įdomią JAV karybos istoriją jis sudèliojo tik į dvi lentynèles, tačiau neatsisakè savo idejjos, jog amerikiečiai sprendimo kare visada siekia kautynėmis ${ }^{10}$. Gali skambėti paradoksaliai, kaip įmanomas karas be kautynių, be mūšio. Istorija galètų paliudyti, jog per ne kartą yra vykę karai, kurie baigdavosi, neįvykus mūšiui, nors abi kariaujančios pusės pasiekdavo tai, ko norėdavo ${ }^{11}$. Šiuo atveju reikia pabrèžti, jog kalbėdamas apie "sunaikinimo strategijos" dominavimą, Weigley nori pasakyti, kad amerikiečiai pergalès pasiekimą kare laikydavo tik pergalę mūšyje, o ne naudą, kurią atnešdavo partizaninis pasipriešinimas ar diplomatinès gudrybès.

\subsection{A. H. Jomini vs C. von Clausewitzas}

Atsakydamas į klausimą - kaip sunaikinimo strategija tapo dominuojančia JAV - Weigley pateikia paprastą atsakymą ir pasako vieną vardą Antoine-Henri Jomini. Tiems, kas nèra susipažinę su JAV karybos istorija (ji kai kuriais atvejais labai stipriai prasilenkia su viešoje erdvëje naudojamais vaizdiniais ir stereotipais), gali nuskambèti keistai, tačiau šių dienų Jungtinių Valstijų karinei minčiai bei visam strateginiam mąstymui didesnę įtaką daro Jomini, o ne Carlas von Clausewitzas ${ }^{12}$. Kaip teigia Colinas, S. Gray, „tikrasis JAV strateginio mąstymo tèvas yra Jomini, o ne Clausewitzas [...]. Jo (Jomini -D. Š.) aiškumo paieškos, manija, sudètingus dalykus sumažinti iki paprastų ir

\footnotetext{
${ }^{9}$ Weigley, xxii.

${ }^{10}$ Linn B. M., „The American Way of War Revisited“ with a response by Russell F. Weigley, The Journal of Military History 66 (April 2002), p. 501-533.

${ }^{11}$ Klasikiniu tokių karų laikotarpiu laikomas XVIII a., kai valstybės dažnai kariaudavo, vykdydamos didžiulius manevrus, arba organizuodamos miestų apsiaustis, bet vengdavo mūšiu, nes nenorėdavo prarasti kariu, kurių rekrutavimas, mokymas ir išlaikymas valstybei kainavo daugybę pinigų. Prarasti didžiają dali karių viename mūšyje, kuris net gali neturèti strateginès reikšmès, nebuvo labai gundanti idejja.

${ }^{12} \mathrm{Abu}$ šie autoriai raše tuo pačiu laikotarpiu. Jie taip pat kaip atspirties tašką savo teorijoms pasirinko Napoleono karus, nes manė, jog jie yra akivaizdus patvirtinimas, kad karyboje įvyko daug rimtu pokyčių. Kadangi Napoleonas buvo ju kūrybos ịkvejpejju, tai abiejų tekstuose galima rasti nemažai panašių idejju. Ju skirtumas iš esmès yra tas, jog A. H. Jomini domino tik pati karyba. Jis siekè surasti universalius karo principus. Todèl jo kūryboje labai aiškiai jaučiama Švietimo epochos kūrëju įtaką, kuri labiausiai pasireiškè tuo, jog A. H. Jomini daug kur taikẻ matematinius, geometrinius metodus. Tuo tarpu C. von Clausewitzas atvirkščiai, jis kritikavo bet kokių universaliu karybos principu paieška, ypatingai taikant matematinius metodus. Jis karą tyrè ne kaip atskirą, bet kaip reiškini, susijusi su kitomis žmogaus veiklomis, pirma, su politika.
} 
aiškių principu, paliko žymę amerikiečių karinëje mintyje ir praktikoje $\mathrm{e}^{\prime 13}$. Šis, iš pirmo žvilgsnio mažas niuansas, turi labai svarbių ir toli siekiančių pasekmių. Kiekviename tarptautinių santykiu, karybos, saugumo studijų vadovėlyje yra teigiama, jog didžiausiu šiuolaikinès strategijos bei karinès minties apologetu reikia laikyti Clausewitzą. Dèl to lyg ir neturètų kilti ginčų. Tačiau galingiausia šių dienų karinè galia - Jungtinès Valstijos - neignoruodamos Clausewitzo, didesnį dèmesį skiria Jomini. O tai reiškia, kad ir amerikiečių požiūris tiek į karybą, tiek į strategiją skiriasi nuo kitų valstybių. Kodèl Jomini, o ne Clausewitzas yra labiau populiarus Jungtinèse Valstijose? I tai savo knygoje puikiai atsako Weigley.

JAV nepriklausomybę iškovojo ir pirmuosius savo žingsnius pradëjo žengti Didžiosios Prancūzijos revoliucijos metais. Amerikiečiai kopijavo europiečius visur, taip pat ir karyboje. O tuo metu karyboje dominavo Napoleono idejjos, jo kariavimo metodai. Šių metodų pagrindinè idëja buvo labai paprasta karas laimimas, kai priešas sutriuškinamas pagrindiniame mūšyje. Napoleono karai buvo Jomini karo teorijos pagrindas. Jo parašytus tekstus gerai įvertino pats Napoleonas, ir tai padèjo, jog šveicarų karininko idejjos tapo labai populiarios Europoje. Nesigilinant i Jomini karo teorijos niuansus, supaprastinus būtų galima teigti, jog svarbiausias jo karo principas buvo sutelkti visas karinès pajègas į vieną vietą ir užtikrintai smogti priešininkui sukoncentravus visą jègą i vieną tašką ${ }^{14}$. Paprastai tariant, Jomini buvo puolamojo karo (ang. offensive war) šalininkas. Jis taip pat savo karo teorijoje daug demesio skyrè logistikai, kadangi tik gerai veikiančios logistikos sistemos dèka į vieną vietą galima sukoncentruoti kariuomenę ${ }^{15}$.

Šiomis Jomini idejomis vadovaujantis buvo parengta ne viena JAV karininkų laida West Point karo akademijoje. O chrestomatiniu jo idejjų pritaikymu praktikoje yra laikomas JAV pilietinis karas $^{16}$. Tačiau ir po šio karo, Jomini išliko karo teorijos autoritetu. Maža to, iš sausumos karybos ji buvo perkelta į jūrų. Tai padarẻ vienas iš geopolitikos pradininkų - Alfredas T. Mahanas. Pagal jo teoriją, pagrindinis laivyno tikslas - priešininko laivyno sunaikinimas. Tik sunaikinus priešo karo laivyną bus galima dominuoti jūrose ${ }^{17}$.

O tai, kad Jomini iki šių dienų išlieka svarbus JAV karinei minčiai ir

\footnotetext{
${ }^{13}$ Gray C. S., „Strategy ins the nuclear age: The United States, 1945-1991“, Murray W., Knox M., Bernstein A., sudar., The making of strategy: rulers, states, and war, Cambridge: Cambridge University Press, 1994, p. 592.

14 Jomini A. H., The art of war, London: Greenhill Books; Pennsylvania: Stackpole Books, 1996.

15 Amerikiečiu karinè logistika visada buvo ir yra laikoma viena stipriausių jos karinès galios elementų. C. S. Gray nuomone, amerikiečių aistra ir didžiulis dėmesys logistikai yra susijęs su JAV susikūrimu, naujų teritorijų užvaldymu: laiku gautos maisto, amunicijos atsargos daugeliu atvejų išgelbėdavo naujakurių gyvybes. (Murray, The making of strategy: rulers, states, and war, 590). Todèl tai gali būti dar viena iš priežasčių, kodèl A. H. Jomini taip patiko amerikiečiams, nes savo tekstuose jis labai daug dẻmesio skyrẻ logistikai.

16 Weigley, p. 92-192.

${ }_{17}$ Mahan A. T., The influence of sea power upon history, 1660-1783, London: Sampson Low, Marston \& co, 1890.
} 
praktikai, puikiai iliustruoja taip vadinamuju „,karo principų“ egzistavimas. Kad palengvintų karininkų ir karių rengimą, amerikiečiai tarpukaryje, remdamiesi Jomini idejomis, sukūrè „karo principus“. 2001 m. JAV sausumos pajègu taktikos vadovèlyje operacijoms FM3-0 išdèstyti tokie karo principai: kariniu pajègu koncentravimas, aiškus tikslas, puolimas, netikètumo efektas, jėgu ekonomijos principas ir kt. ${ }^{18}$

Apibendrinant šią trumpą Jomini idèjų įtaką, reikètų užsiminti, jog amerikiečiams nebuvo svetimos ir Clausewitzo idejjos. Tačiau pastarasis karo teorijos klasiku tapo tik antroje XIX a. pusëje. Jo rašymo stilius buvo kur kas sudètingesnis, filosofiškesnis nei Jomini. Tikriausiai todèl, kaip dabar sutinka daugelis mokslininku, Clausewitzo idejjos buvo klaidingai interpretuojamos. Jo idejjos, pasiūlymai būdavo ištraukiami iš konteksto. Taip pat reikia pastebèti, jog iš pirmo žvilgsnio atrodè, jog Clausewitzo idejjos daug kur sutapo su Jomini mintimis. Vokietis savo knygoje ne kartą užsimena apie mūšio svarbą, kariuomenès koncentraciją, jos sutelkimą ties labiausiai pažeidžiama priešo vieta ir pan. ${ }^{19}$ Šis faktas turëjo itin svarbias pasekmes JAV karinei minčiai. Kadangi atrodè, jog Clausewitzas nesiūlo nieko naujo, lyginant su Jomini, tai amerikiečiai paprasčiausiai skyrė mažiau dẻmesio vokiečių teoretiko idejjoms.

Clausewitzas tam tikru laikotarpiu patraukdavo aukšto rango karininku ir politikų dėmesi, ypač po pralaimèjimo Vietname ${ }^{20}$. Tačiau šie susidomèjimai visada būdavo trumpalaikiai. Po pirmojo Persijos įlankos karo prasidejo diskusijos apie revoliuciją karybos srityje (ang. RMA), buvo prabilta apie tai, jog arteja momentas, kada Clausewitzas bus įveiktas. Naujos karinės technologijos, kompiuteriai ir t. t. yra laikomi tais vaistais, kurie įveiks „,karo rūką“"21.

Amerikiečiai gana sunkiai susitaiko su Clausewitzo „frikcijos“ idëja, kuriose esmè yra tai, jog karas realybejje skiriasi nuo to karo, kuris yra suplanuojamas ir parašomas popieriuje. Geriausi planai gali būti sugriauti dèl pakitusių oro sąlygų, dèl karių fizinio nuovargio, alkio, informacijos trūkumo ir t. t. ${ }^{22}$ Tuo metu naujausios technologijos tarsi leidžia viso šito išvengti. Kosmoso palydovų dèka galima kuo puikiausiai žinoti, kur yra priešininkas, ką jis

\footnotetext{
${ }^{18}$ US Army, Field Manual FM 3-0, Operations, 2001, http:/ /www.globalsecurity.org/military/ library/policy/army/fm/3-0/index.html, 20070825.

${ }^{19} \mathrm{C}$. von Clausewitz, On War. edited and translated by Michael Howard and Peter Paret. Princeton, N. J.: Princeton University Press, 1976, p. 204.

${ }^{20}$ Po pralaimėjimo Vietname JAV kariškiai daug dėmesio skyrè analizei, stengiantis išsiaiškinti, kodèl karas Indokinijoje buvo nesėkmingas. Tuo metu labai įtakinga tapo pulkininko H. Summerso atlikta analizè, kuria jis pagrindè Clausewitzo idèjomis. Pagrindinè H. Summerso išvada buvo ta, kad kariškiai buvo politiku ịrankis, todèl būtina stiprinti ryšius su jais ir stengtis, jog jie nepriimtų sprendimu, kurie būtų visiškai nelogiški karine prasme. Summers H. G., On strategy: a critical analysis of the Vietnam War, New York: Dell, 1984.

${ }^{21}$ Labai iškalbingas yra W. Murray straipsnis „Clausewitz out, computer in“ žurnale The National Interest, kuriame nuosekliai ir aiškiai parodo JAV kariškių domejjimosi C. von Clausewitzo tendencijomis ir galimomis to pasekmėmis. Murray W., „Clausewitz out, computer in: Military Culture and Technological Hubris", The National Interest, June 01,1997.

${ }^{22}$ Clausewitz, 104.
} 
veikia; kompiuterinės ir komunikacinės technologijos leidžia apdoroti didžiulį kiekį informacijos, ją greitai nusiųsti kariams į mūšio lauką. Todèl skaitant įvairių JAV ekspertų, kariškių akademinius tekstus, samprotavimus, susidaro įspūdis, jog amerikiečiai kone patologiškai nori paneigti Clausewitzo „frikcijos“"idejją ${ }^{23}$. Kai kuriais atvejais netgi galima teigti, jog gynybos planuotojai siūlo ir bando igyvendinti gana radikalius projektus ir idejjas. Būtu galima paminèti įvairius bandymus sukurti preparatus, kurie kariams leistų įveikti nuovargi, alki, skausmą. Nepaisant didžiulio mokslinès fantastikos prieskonio, gana rimtai yra žiūrima ir eksperimentuojama bandant sukurti kažką panašaus į karį tarsi „kibernetinị organizmą“ (ang. cyborg) ${ }^{24}$. Taip pat nemažai lěšų skiriama taip vadinamajai kariuomenès „,robotizacijos" programai, kurios tikslas yra sukurti kaip ímanoma daugiau automatiškai valdomų mašinu, robotu, kurie galètų atlikti daugybę darbų, palengvintų karių darbą ${ }^{25}$. Visa tai galima pavadinti bandymu rasti būdą, kaip kontroliuoti žmogaus elgesį mūšyje arba net ji pakeisti mašina, kad būtų išvengta nesklandumų ir klaidu, taip panaikinant „frikcijos“ poveikį.

\subsection{Kitos „amerikietiškosios kariavimo tradicijos“ koncepcijos}

Weigley pateikta amerikietiškosios kariavimo tradicijos koncepcija buvo nemažai kritikuojama. Kaip jau buvo minèta, pats autorius po kurio laiko teigė, jog kai ką koreguotų. Labiausiai jis buvo kritikuojamas, jog labai supaprastino JAV karinę istoriją ir pamiršo daug svarbių dalykų ${ }^{26}$. Taip pat jis buvo kritikuojamas dèl įvairių istorinių netikslumų. Be išsakytų priekaištu, Weigley pasiūlyta idejja,jog amerikiečiai turi savo specifinę kariavimo tradiciją, buvo nepaneigta ir labai greitai buvo pradètos paieškos tų specifiniu, tik JAV karybai būdingų bruožų. Vieni teigè, jog amerikiečių karyba išsiskiria tuo, kad jie labiau pripažǐsta ugnies (ang. fire) svarbą nei manevravimą ${ }^{27}$. Kiti labai išskyrẻ amerikiečių beveik fanatišką tikëjimą įvairiomis technologijomis ir ju teikiamomis galimybėmis $\mathrm{kare}^{28}$.

Turbūt didžiausiu Weigley kritiku būtų galima laikyti Maxą Bootą, ku-

\footnotetext{
${ }^{23}$ Adam T. K., "Future Warfare and the Decline of Human Decisionmaking", Parameters, Winter 2001-02, 61, http:/ / carlisle-www.army.mil/usawc/Parameters/01winter/adams.htm, 04102007 ; Watts B. D., Clausewitzian Friction and Future War. Washington: Institute for National Strategic Studies of National Defense University, 2000, 23, http://www.clausewitz.com/CWZHOME/ Watts2/FrictionTOC.htm, 2007-10-13; Owens W. A., Offley E., Lifting the Fog of War, Baltimore: The Johns Hopkins University Press, 2001.

${ }^{24}$ Gray Ch. H., Postmodern war: the new politics of conflict, London: Routledge, 1997.

${ }^{25}$ Graham S., „America's robot army“, New Statesman, Monday 12th June 2006.

${ }^{26}$ Linn.

${ }^{27}$ Scales R. H., Jr., Yellow smoke: the future of land warfare for America's military, Lanham, Md.; Oxford: Rowman \& Littlefield Publishers, 2003.

${ }^{28}$ Boot M., "The New American Way of War", Foreign Affairs Vol. 82, No. 4, July/August 2003, p. 41-58; Cebrowski A. K., Thomas Barnett P. M., „The American Way of War“, Transformation Trends, January 13, 2003; Cheney D., A New American Way of War, kalba, sakyta Heritage Foundation, May 1, 2003.
} 
ris pateike kitokią amerikietiškosios kariavimo tradicijos versiją. Anot Booto, Weigley atliktas tyrimas koncentruojasi ties konvenciniu, "didžiuoju“ karu. Tačiau, Booto teigimu, JAV turi ir kitą labai seną kariavimo tradiciją. Jie nuo pat valstybės įkūrimo be perstojo kariavo įvarius „mažuosius“ karus užsienyje, kurie kartais apsiribodavo tik vieno būrio išlaipinimu, o kartais užtrukdavo ne vienerius metus ${ }^{29}$. Savo knygoje jis aprašo JAV karinio laivyno, jūru pėstininku atliktas misijas Lotynų Amerikoje, Ramiojo vandenyno salose, Azijoje, Europoje. Jo teigimu, daugeliu atveju apie tuos konfliktus ir amerikiečių karių vaidmeni juose net ir tuo metu, kai jie vykdavo, buvo mažai žinoma. Visuomenę, anot jo, labiau domino, ką vedè koks nors milijonierius, nei ką už šimtų kilometrų veikia JAV kariai. Todèl, Booto teigimu, nieko nuostabaus, jog šiais laikais apie šiuos mažus karus ir konfliktus beveik nieko nežinoma. Ne veltui jie yra vadinami „užmirštaisiais karais". Tačiau atsižvelgiant į tai, kaip dažnai JAV kariavo ir kariauja tokio tipo karuose, būtų galima pagrịstai klausti, ar konvenciniai, , didieji“", karai yra taisyklè, o gal išimtis Jungtinių Valstijų kariavimo istorijoje?

Booto aprašyti konfliktai ir tos pamokos, kurias išmoko JAV kariai, o ypač jūrų péstininkai, jei vertinsime šių dienų įvykius, tampa labai reikšmingi. Kaip tik šių, mažuju, karų metu, JAV kariai užsiẻmė tuo, ką šių dienų JAV kariškiai daro Irake, Afganistane. Jie užsiima valstybės atstatymu (ang. state rebuilding), taikos palaikymu (ang. peacekeeping), sėkmingai kovoja su islamistu kovotojais (Filipinuose, $X X$ a. pr.) ${ }^{30}$. Tačiau visų šių misijų istorija turi ir kitą monetos pusę. Beveik visais atvejais, JAV kariams pasitraukus iš valstybių, jose vyravęs stabilumas netrukdavo sugriūti. Taip atsitikdavo, nes visose šiose misijose viską darydavo kariškiai, o kitos JAV institucijos neprisidėdavo prie stabilumo kūrimo ${ }^{31}$. Todèl amerikiečių kariai būdavo priversti po kurio laiko iš naujo vykti į valstybes (ypač Centrinejje Amerikoje), kuriose neseniai buvo, ir vèl imtis atkurti tvarką. Kaip tik tai, pasak Antullio J. Echevarrios, vieno garsiausio ir įtakingiausio šių dienų karo tematika rašančio JAV kariškio, leidžia teigti, jog pabaigoje, Bootas nesukritikuoja, bet papildo ir sustiprina Weigley ideją. Anot Echevarrios, tai visai nepaneigia Weigley teorijos, bet netgi ją papildo. Abi teorijos sutaria dèl to, kad "Amerikos kariavimo tradicija pasižymi polinkiu šalintis nuo sudètingo karinių laimejjimų pavertimo strategine šalies politikos sẻkme proceso, nepaisant ar tai būtų didelio masto kampanijos, ar nedidelès vieno dalinio vykdytos misijos" ${ }^{\prime 2}$.

\footnotetext{
${ }^{29}$ Boot M., The Savage Wars of Peace: Small Wars and the Rise of American Power, New York: Basic Books, 2002.

${ }^{30}$ Būtuc galima diskutuoti, ar priemones, tikusios $X X$ a. pr., yra tinkamos $X X$ a. pab. ir XXI a. pr. Turbūt geriausias atsakymas būtu JAV jūrų péstininkų „Mažuju karų vadovas“, sudarytas dar 1940 m., tačiau iki šiol pasaulyje laikomas vienu geriausiu teoriniu tekstu apie taktiką tokio tipo karuose. Small Wars Manual, United States Marine Corps, 1940, http:/ /www.au.af.mil/au/awc/ awcgate/swm/index.htm, 2007-10-15.

${ }^{31}$ Echevarria II A. J., Toward an American Way of War. Strategic Studies Institute, U. S. Army War College, 2004, p. 6, http://www.strategicstudiesinstitute.army.mil/pdffiles/PUB374.pdf, 200707-10.

${ }^{32}$ Echevarria, p. 7.
} 


\subsection{Mūšio tradicija}

Echevarria žengia dar toliau nei Weigley. Anot jo, JAV iki šiol neturi savo kariavimo tradicijos. Tai, apie ką rašè Weigley, jis vadina „mūšio tradicija“ (ang. a way of battle). Echevarrios teigimu, Weigley teisingai pastebëjo, jog amerikiečiai karo samprata niekad neperžengė mūšio, karinės kompanijos sampratos ribų ${ }^{33}$. Jie, „priešingai nei europiečiai, karą laikẻ alternatyva visoms diplomatinėms deryboms, o ne kaip vieną iš sudedamuju viso derybų proceso dalių “34.

Šiuo savo pastebëjimu Echevarria aptarè vieną didžiausią karo teorijos diskusiją - kuo skiriasi karo (ang. war) ir kovos (ang. warfare) koncepcijos. Labai dažnai šios dvi sąvokos yra suliejamos į vieną arba naudojamos kaip sinonimai. Tai iš dalies galima paaiškinti tuo, kad vyraujantis karo įvaizdis ir samprata visuomenėse yra asocijuojamas su mūšiu. Kartais galima išgirsti ir tokių absurdiškų pasakymu, jog konflikto negalima laikyti karu, nes nebuvo jokių mūšių. Tačiau istorija pilna pavyzdžiu, kai vykdavo karai, tačiau nebūdavo mūšių ${ }^{35}$.

Karo ir kovos koncepcijos iš principo nėra lygiavertės. Karas yra ne tik kova, tai teisinė, socialinė sąvoka, kategorija. Karas yra ne tik kova. Karas tai ir pasiruošimas kovai, ir procesai, vykstantys po kovos. Tuo tarpu kova yra ta karo fazè, kurioje vyksta susidūrimas, liejamas kraujas. Valstybės ir kiti politiniai junginiai „pradeda kovas tam, kad laimètu karus “36. Gray teigimu, Napoleonas ir vokiečiai abiejų pasaulinių karų metu rodė stebuklus kovos lauke, tačiau jie nesugebėjo laimèti karu, nes kova mūšio lauke dar nereiškia pergalès kare $^{37}$. Šioje vietoje verta prisiminti Clausewitzo žodžius, jog karo tikslas yra "priversti priešininką paklusti tavo valiai“" ${ }^{\prime 3}$. Kova yra svarbus elementas, bet ne vienintelis, ir ne visada svarbiausias. Galima rasti įvairiu būdų priversti priešininką paklusti. Pergalę mūšio lauke galima paversti pergale kare, tačiau tam reikia mokèti strategiškai mąstyti, reikia mokèti pergalę išnaudoti strategiškai ${ }^{39}$.

Kaip tik šio sugebëjimo - pergale mūšyje paversti pergale kare, anot Echevarrios, kaip tik ir trūksta amerikiečiams. Tai puikiai iliustruoja tokie pavyzdžiai: karas Vietname ir dabartinės operacijos Irake bei Afganistane.

\footnotetext{
${ }^{33}$ Visa tai puikiai patvirtina ir "darbo pasidalijimo“ idejja, kurią europiečiams siūlo JAV. Pagal šią idèją, JAV užsiima "griovimu ir naikinimu“ - kariniais veiksmais, o europiečiai vèliau užsiima tvarkos ir stabilumo atstatymu.

${ }^{34}$ Echevarria, p. 1.

${ }^{35}$ Šiuo atveju, kai yra kalbama apie mūšı̆i, omenyje turimas didelis, generalinis mūšis (Austerlico, Borodino ir t. t.), o ne maži susidūrimai vykdant žvalgybą ir pan.

${ }^{36}$ Gray C. S., War, peace and international relations: an introduction to strategic history. London: Routledge, 2007, p. 6.

${ }^{37}$ Savo knygoje H. Summersas prisimena pokalbị su Vietnamo karininko, kurio metu Summersas pašnekovui teigè, jog vietnamiečiai niekad neįveikẻ amerikiečių karių. Vietnamietis su tuo sutiko, tačiau, anot jo, karas baigėsi vietnamiečiu pergale, Summers, p. 1.

${ }^{38}$ Clausewitz, p. 75.

${ }^{39}$ Gray, p. 7.
} 
Karinès pergalès operacijose nebuvo paverstos arba iki šiol sunkiai jas galima paversti pergalėmis kare. Amerikiečiai nenoriai pripažįsta faktą, jog karas neapsiriboja vien karo veiksniais. Tą puikiai iliustruoja dar vienas įdomus amerikiečių karinès minties produktas, tai kitų nei karas misiju koncepcija (ang. military operations other than war $)^{40}$. Daugiausia šioms misijoms priskiriamos operacijos, kurios būna vykdomos, kai pasibaigia kovos veiksmai. Ši koncepcija puikiai parodo, jog tai, ką teoretikai vadina kova (ang. warfare), amerikiečiai linkę vadinti karu.

\subsection{Kitụ valstybiụ patirtis}

Ši amerikietiška „mūšio" tradicija dar labiau išryškëja, kai palyginame su kitų valstybių ar regionu praktika. Britiškoji kariavimo tradicija, lyginant su amerikietiškaja, yra kur kas sudètingesnè ir subtilesnè. Britai jau nuo karalienès Elžbietos laikų XVI a. naudojo įvairius metodus kare: karinį - veiksmai jūrose ir sausumoje, ekonomini - Ispanijos kolonijų plèšimas, laivų, gabenančių Madridui sidabrą, grobimas (tai taip pat buvo kariniai veiksmai, tačiau ju potekstė ir tikslas buvo ekonominis) ${ }^{41}$. Sios tradicijos pėdsakus lengvai galime atsekti per visus laikotarpius iki pat Pirmojo pasaulinio karo. Kitas britų kariavimo bruožas yra susijęs su jų imperijos plètimu ir išlaikymu. Britai, norèdami išlaikyti savo didžiules valdas, kovojo daugybę mažų karų. Šioje vietoje būtų galima atrasti nemažai paralelių tarp Booto aprašytų JAV „mažujų “ ir Viktorijos laikų karų. Tačiau priešingai nei amerikiečiai, britai kur kas labiau įsisavino šių karų pamokas ${ }^{42}$. Apie britų karybą būtų galima sakyti, jog ",teorijoje ji buvo „eurocentrinè", bet praktikoje - ne “43. Tai reiškia, jog politikai, kariškiai, o vèliau ir istorikai labiausiai kalbejjo apie D. Britanijos karus Europoje, nors iš tiesų ji daug ilgiau ir intensyviau kariavo kolonijose. Jose britų kariai igijo daug praktikos kariaujant „mažus karus“ , kurie daugeliu atveju būdavo labiau ne karinès, bet psichologinès, ekonominès operacijos, kuriose labai stipriai buvo bendradarbiaujama su civiliais. „Mažujų " karų tradicija buvo tęsiama ir Šaltojo karo metais: dekolonizacijos iššaukti konfliktai, neramumai Š. Airijoje. Todèl, priešingai nei JAV, kur aukščiausius karinius postus užėmė konvenciniu karų ekspertai, D. Britanijoje iki pat šių dienų aukštus postus užima kariškiai,

\footnotetext{
${ }^{40}$ Tokioms misijoms priskiriamos ginklų kontrolés, taikos palaikymo, taikos įtvirtinimo, humanitarinès pagalbos ir panašios operacijos.

${ }^{41}$ Howard, p. 172.

${ }^{42}$ Kaip pavyzdị būtų galima paminèti britų karininko C. E. Callwello dar 1896 m. išleistą knygą Small wars, kuri iki šiol yra laikoma vienu geriausiu veikalu apie partizanini, nekonvencinị karą. Callwell C. E., Small war: a tactical textbook for imperial soldiers, London: Greenhill Books/Lionel Leventhal, 1990.

${ }^{43}$ Strachan, p. 405.
} 
turintys nekonvencinio karo patirties ${ }^{44}$. Apibendrinant galima teigti, jog britu karo samprata tikrai nepasiriboja vien karinio įrankio panaudojimu.

Panašią išvadą būtų galima daryti ir apie prancūzų karybos tradiciją. Prancūzai, nepaisant Napoleono karinio palikimo ir tradicijų taip pat dèl ilgalaikiu karų savo užjūrio imperijoje, buvo gana geri ekspertai nekonvenciniame kare.

Bandydami sujungti britišką, prancūzišką bei kitų Europos valstybių karinę patirti, ekspertai bei teoretikai net prabilo apie „europietišką" kariavimo tradiciją ${ }^{45}$. Pagrindiniu jos skiriamuoju bruožu yra laikoma didelè patirtis, atliekant stabilizavimo, taikos palaikymo, kontrteroristines operacijas ${ }^{46}$. Tai yra kaip tik tokio tipo operacijos, kurioms amerikiečiai iki šiol skyrè gana mažai dėmesio. Taip pat tai yra tokio tipo operacijos, kurios reikalauja didesnio kariškių ir civilinių institucijų bendradarbiavimo.

Apibendrinant būtų galima teigti, jog europiečiai į karą žiūri kur kas sudètingiau. Jiems karas nèra vien karo veiksnio panaudojimas. Tačiau Bootas gana puikiai parodė, jog ir JAV turi panašią patirti kaip Europos valstybės. Tada kodèl amerikiečiai iš to padarè gana menkas išvadas ir kodèl nepasimokè iš istorijos. Šiuo atveju būtų galima teigti, jog Booto pateikti pavyzdžiai gali būti laikomi puikiais lakmuso popierèliais, kurie leidžia identifikuoti vieną specifinį amerikiečių charakterio bruožą, kuris, anot mokslininkų, daro didelę įtaką JAV užsienio, o ypač gynybos politikai bei karybai.

\subsection{Istorijos neigimas}

Booto pateiktus pavyzdžius būtų galima laikyti visiška priešingybe, lyginant su tuo, ką teigè ir teigia JAV aukščiausi kariškiai, kurie svarbiausia JAV kariavimo tradicija laiko kovą "didžiuosiuose“ karuose. Perskaičius šio autoriaus knygą, natūraliai kilo klausimas. Kodèl JAV, turèdama tokią didelę dalyvavimo patirti mažuosiuose karuose, taip sunkiai „tvarkosi“ Irake ir Afganistane? Taip pat pavarčius tiek akademinius, tiek publicistinius tekstus galima aptikti dažnai užduodamą kitą klausimą, o kaip Vašingtonas Irake sugebejjo pakartoti Vietnamo karo klaidas? Gray ir kitų akademikų nuomone, atsakymas slypi amerikiečiu požiūryje į istoriją.

Anot Gray, ,JAV iki šiol tam tikra prasme yra naujasis pasaulis. Todèl čia nèra labai populiarios istorijos studijos. [...] Istorijos studijos ir istorinès patirtis yra amerikiečių ignoruojamos. JAV ne tik yra abejinga istorinei praeičiai ir jos pamokoms, jos kultūra yra prieš istoriją. [...] Todèl dažnai būna atrandami jau ir taip aiškūs dalykai, kartojamos senos klaidos“47. Visiems gana gerai

\footnotetext{
${ }^{44}$ Strachan, p. 406; Robert M. Cassidy, ,"The British Army and Counterinsurgency: The Salience of Military Culture", Military review, May -June 2005, p. 53-59.

${ }^{45}$ Everts S., Freedman L., Grant Ch., Heisbourg F., Keohane D., O’Hanlon M., sudar., European Way of War, London: Centre for European Reform, 2004.

${ }^{46}$ Everts, p. 2, 25.

${ }^{47}$ Gray, Strategy ins the nuclear age: The United States, 1945-1991, p. 592.
} 
yra žinomas amerikiečių tikejjimas, jog jie yra Dievo išrinktoji tauta ir kad jos propaguojamos vertybès yra geriausios, todèl jas turi perimti kitos pasaulio tautos, valstybės. Išrinktajai tautai neverta dairytis į praeiti, nes jos sprendimai ir veiksmai yra teisingi, todèl reikia žvelgti tik į ateitį.

Tokių nuostatų i̇taką JAV užsienio, o tuo pačiu ir gynybos, politikai nesunku aptikti. Užtenka prisiminti dabartinio Jungtinių Valstiju prezidento G. W. Busho kalbas, kur ne kartą beveik su religiniu fanatizmu buvo kalbama apie būtinybę skleisti pasaulyje demokratiją. Daug kas teigtu, jog tokios kalbos yra tik bandymas maskuoti imperialistines JAV ambicijas, geopolitiniais ir "tikros" politikos (ang. realpolitik) interesais pagrịstą politiką. Būtų galima su tokiais argumentais sutikti, tačiau būtina atsižvelgti į tai, jog, kalbėdamas apie demokratijos plètrą, G. W. Bushas, kaip ir daugelis politiku prieš ji (ypač W. Wilsonas), nuoširdžiai tikèjo ir tiki amerikiečių tautos išskirtinumu bei jos misija pasaulyje ${ }^{48}$.

Įvairūs socialiniai tyrimai patvirtina Gray žodžius. Šių dienų JAV mokyklose bei universitetuose skiriamas minimalus dėmesys bendram istoriniam išsilavinimui. Moksleivių ir studentų apklausos parodė, jog jie nežino elementarių faktų iš JAV istorijos, todèl net neverta kalbèti apie kitų valstybių ir regionų istorijos pažinimą ${ }^{49}$. Kaip teigiama vienoje iš ataskaitu, „, ateities šalies lyderiai igauna išsilavinimą beveik nieko nežinodami apie savo istorini palikimą"50.

Visuomenëje vyraujančios nuotaikos, nuostatos atsispindi ir JAV karinio švietimo sistemoje. Susipažinus su gynybos ekspertu, pačių JAV kariškių vertinimais, galima konstatuoti, jog istorijai Jungtinių Valstijų gynybos koledžuose, akademijose skiriamas demesys nekelia optimizmo. Per paskutinius 50-60 metų požiūris į istorijos naudą būsimų karininkų išsilavinimui kardinaliai keitèsi mažiausiai tris kartus. Iš karto po II-ojo pasaulinio karo istorija buvo viena iš svarbiausių karo akademijose déstomų disciplinų. Tačiau 50-aisiais, 60-aisiais, dèl socialiniuose moksluose vyraujančių pozityvistinių tendenciju bei dèl branduolinio ginklo svarbos didejjimo, karininkų švietime vis didesnis

\footnotetext{
${ }^{48}$ Tai nereiškia, jog, ịgyvendinant Dievo pavestą misiją, nereikia vykdyti agresyvios politikos, atvirkščiai - daugeliu atveju ji yra privaloma. Robertas Kaganas savo naujausioje knygoje bando įrodyti, jog amerikiečiai dar nuo kolonijų įkūrimo laikų buvo labai agresyvi tauta, gana noriai savo tikslams pasiekti naudojanti karines priemones. Ir tam labai didelę įtaką turëjo religija. Kagan R., Dangerous Nation: America in the World 1600-1900, New York: Atlantic Books, 2006. Apie religijos vaidmenį JAV užsienio politikai gana daug dèmesio skiria Walteris Russelas Meadas. Mead W. R., Special providence: American foreign policy and how it changed the world, New York: Knopf, 2001; Mead W. R., "God's country?", Foreign Afairs, September/October 2006.

${ }^{49}$ Stern Sh. M., Effective State Standards for U.S. History: A 2003 Report Card, Thomas B. Fordham Institute, 2003 September, http:/ / www.fordhaminstitute.org/institute/publication/publication. cfm?id=320, 2007-10-18; Martin J. L., Losing America's Memory: Historical Illiteracy in the 21st Century, American Council of Trustees and Alumni, 2000, http:/ / www.goacta.org/publications/reports. html, 2007-10-18. Situacijos rimtumą patvirtina ir tai, jog JAV Senatas $2000 \mathrm{~m}$. priemė rezoliuciją, kurioje išreiškiamas susirūpinimas dèl istorijos mokymo problemu ir raginama imtis skubiu priemoniu, kurios padėtu pašalinti egzistuojančius trūkumus. S. CON. RES. 129, Expressing the sense of Congress regarding the importance and value of education in United States history, June 30, 2000, http:/ /www.goacta.org/publications/Reports/congressres.htm, 20071018.
}

${ }^{50}$ Martin, p. 2. 
dèmesys buvo skiriamas ịvairioms vadybos, sistemų analizės disciplinoms. Istorija beveik buvo pašalinta iš mokomuju programų $u^{51}$. Situacija pasikeitė po Vietnamo karo, kai buvo pradèta aiškintis, kodèl amerikiečius Vietname ištiko nesèkmè. Atsakymu i daugeli klausimu pradèta ieškoti praeityje, o tai paskatino istorijos, ypač karo disciplinu, sugrị̌zimą i karo akademiju mokymo programas. Tačiau akademiku ir kariškių teigimu, situacija vėl pradejjo kardinaliai keistis po Pirmojo Persijos įlankos karo. Susižavejjimas naujomis karinėmis technologijomis ir jų suteikiamomis perspektyvomis vèl vertè klausti, kam reikalinga istorija ${ }^{52}$. Buvo manoma, jog naujos technologijos taip stipriai pakeis karybą, jog nebus jokios naudos ieškoti pavyzdžiu praeityje. Ironiška, bet galima konstatuoti, jog JAV kariškiai nepasimokẻ iš istorijos ir pradejjo kartoti Vietnamo laikų klaidas. Apibendrinant būtų galima teigti, jog požiūris ị istoriją JAV kariškių bendruomenèje keičiasi su kiekviena nauja karininkų karta. Toks svyravimų dažnumas tikrai nepadeda tam, kad amerikiečiai geriau suprastų praeityje darytas klaidas ir iš ju pasimokytur.

Paanalizavus šiu dienų JAV gynybos politiką, vyraujančias karines idejjas ir mintis, galime rasti ne vieną pavyzdị, kuris patvirtina istorinės analizès ir istorinio supratimo trūkumą JAV gynybos politikoje. Jau minèti Booto aprašyti „užmirštieji“ karai ir juose sukaupta patirtis, kuri šiomis dienomis yra atrandama iš naujo ${ }^{53}$. Taip išsireiškimas „užmirštieji karai“ nebeskamba juokingai, o puikiai iliustruoja požiūrị į istoriją ir jos pritaikymą praktinejje politikoje ${ }^{54}$.

Nenoras ir tuo pačiu nesugebejimas pasimokyti iš praeities klaidu, pabandyti suprasti, kas ir kodèl buvo blogai, yra dar viena priežastis, leidžianti Weigley „sunaikinimo“ strategijai ir toliau dominuoti JAV gynybos politikoje bei karyboje. Kreipdami mažai dėmesio istorijai, JAV kariškiai turi gana menką supratimą, jog egzistuoja alternatyvos „sunaikinimo“strategijai. Atrodo, jog

\footnotetext{
${ }^{51}$ Sinnreich R. H., „'Awkward partners: military history and American education“, cituota iš Murray W. ir Sinnreich R. H., sudar., The past as prologue: the importance of history to the military profession, Cambridge: Cambridge University Press, 2006, p. 58-59.

${ }^{52}$ Van Riper P. K., "The relevance of history to the military profession: an American Marine's view“, cituota iš Murray W. ir Sinnreich R. H., sudar., The past as prologue: the importance of history to the military profession, Cambridge: Cambridge University Press, 2006, p. 52-53.

${ }^{53}$ Būtų galima paminèti dar vieną priežastị, kodèl šios mažų karu pamokos buvo ignoruojamos. Beveik visas tokio pobūdžio misijas vykdé jūru pèstininkai, kai kurios kitos kariuomenès rūšys, ypač sausumos pajėgos ilgą laiką labai nemėgo. Konkurencija tarp kariuomenės rūšių nėra tik JAV būdingas bruožas, tačiau Jungtinėse Valstijose ji turi labai senas ir gilias istorines šaknis.

${ }^{54}$ Viena svarbiausių pastarujų dešimtmečiu JAV gynybos politikos produktų - Powello doktrina puikiai patvirtina, kad Booto siūloma ir propaguojama JAV „mažujų karu“ tradicija buvo ir yra labai svarbi, paverčiant JAV pasaulio hegemone, bet yra ignoruojama. Svarbiausia jos idejja yra ta, jog amerikiečiai dalyvauja tik tuose kariniuose konfliktuose, kurie yra svarbūs JAV nacionaliniam saugumui, misijos tikslai yra aiškiai apibrèžti, yra numatyta aiški pasitraukimo strategija ir t. t. Paprastai tariant, JAV dalyvauja tik svarbiuose kariniuose veiksmuose, užsiima tik kariavimu, o ne kitokio pobūdžio misijomis. Powell C. L., "U.S. Forces: Challenges Ahead“, Foreign Affairs. 1992 Winter.
} 
prieš šimtą metų tuometinio JAV prezidento T. Roosevelto žodžiai, jog „,amerikiečiai mokosi tik iš katastrofu, bet ne iš turimos patirties", išlieka aktualūs ir šiandien ${ }^{55}$.

\subsection{Revoliucija karybos srityje}

İvertindamas šiuo metu vyraujančias JAV gynybos politikos tendencijas A. Echeverria teigia, jog Vašingtonas toliau tęsia „mūšio tradicijos“ palaikymo politiką. Konkrečiai šiuo atveju jis omenyje turi tai, ką akademikai vadina „revoliucija karybos srityje“ (RKS), o politikai - transformacija ${ }^{56}$.

Jau beveik du dešimtmečius JAV gynybos ir saugumo bendruomenė be perstojo kalba apie RKS svarbą ir reikšmę. Tikslaus pataikymo ginklai, „protingos" bombos, nepilotuojami orlaiviai (ang. UAV), karinès srities kompiuterizacija, virtualizacija, tinklinio karo doktrina (ang. network centric warfare), kosmoso palydovai ir kt. Visa tai, pasak kariškiu, ekspertu, politiku, keičia karybą kaip revoliucija. Lemiamu veiksniu kare tampa greitis - kuo greičiau gauti informaciją, ją išanalizuoti, priimti sprendimą ir jị igyvendinti. Todèl šiu dienų karinès pajègos turi būti mobilios, mažos, lengvai perdislokuojamos. Tam, kad norimas rezultatas būtų pasiektas greitai, vis labiau skatinamas kariuomenės rūšiu bendradarbiavimas ${ }^{57}$. Visa tai yra šiu dienų gynybos, saugumo, karybos ekspertų debatų ir diskusijų branduolys. Ginčijamasi dèl atskiru aspektu, niuansu, tačiau iš principo sutariama, jog tai RKS iš tikruju vyksta. Yra teigiama, jog ji tik įsibėgèja, nes mokslo pasiekimai leidžia sakyti, kad artimiausiu metu pasiekimai biofizikoje, biochemijoje, nanotechnikoje tik dar labiau pagreitins RKS.

Tačiau, žvelgiant į visus šiuos pokyčius per amerikietiškos kariavimo tradicijos prizmę, būtu galima teigti, jog jie ne tik nekeičia šios tradicijos, bet tik ją sustiprina. Kaip teigė JAV generolas Anthony Zinis, - „JAV kariuomenė tampa profesionalesnè žudymo ir griovimo srityje ${ }^{\prime 58}$. Visi šie nauji pajėgumai, ginklai, doktrinos iš tiesų JAV kariuomenę daro beveik nenugalimą mūšio lauke. Tačiau mūšio, o ne karo. Būtų galima konstatuoti, jog JAV tiek politinė, tiek karinė biurokratija paskutinius aštuoniolika metų su dideliu noru ir ịkarščiu dirbo bei savo dèmesị koncentravo ties tuo, kaip reikètų laimèti kovą, bet ne tai, kaip pergalę mūšyje paversti pergale kare. Todèl be akivaizdžių Irako,

\footnotetext{
${ }^{55}$ Roosevelt T., Theodore Roosevelt: an autobiography, New York: Da Capo, 1985, p. 204.

${ }^{56}$ Echevarria, p. 8.

${ }^{57}$ Cebrowski A. K., and John Garstka J., „Network-Centric Warfare: Its Origin and Future“, Naval Institute Proceedings Magazine, 1998, January, http:/ /www.usni.org/Proceedings/Articles98/PROcebrowski.htm, 1007 2007; Murray W., ",Thinking About Revolutions in Military Affairs", Joint Force Quarterly, 16, Summer 1997, 69-76, http://www.dtic.mil/doctrine/jel/jfq_pubs/1416pgs. pdf, 2808 2007; Edwards S. J. A., Swarming on the Battlefield: Past, Present, and Future.RAND, 2000, http://www.rand.org/pubs/monograph_reports/MR1100/index.html, 2007-08-20.

${ }^{58}$ Echevarria, p. 10.
} 
Afganistano pamokų sunku tikètis, jog amerikiečiai staiga imtų ir pakeistų savo požiūrị.

Apibendrinant galima teigti, jog amerikietiškoji kariavimo tradicija ir toliau lieka iš esmès orientuota ị mūšǐ ${ }^{59}$. Dar daugiau, kad šią tradiciją, nors ir netiesiogiai, kopijuodamos JAV vykdomą karinę reformą, perima ir kitos valstybès ${ }^{60}$.

\section{NATO transformacija ir amerikietiškoji kariavimo tradicija}

Turbūt pats ryškiausias pavyzdys, kaip JAV vyraujančios karybos idëjos yra perkeliamos į kitus regionus, yra šiuo metu vykstanti NATO transformacija. Jau vien žodžio transformacija naudojimas parodo, kieno pavyzdžiu seka NATO.

Trumpai prisimenant istoriją, NATO transformacijos pradžia būtų galima laikyti $2002 \mathrm{~m}$. Aljanso viršūnių susitikimą, vykusị lapkričio mėnesi Prahoje. Tada priimtoje deklaracijoje buvo nuspręsta sukurti Greitojo reagavimo pajejgas (ang. NRF - NATO Response Forces). Taip pat nuspręsta reformuoti NATO vadaviečių struktūrą ${ }^{61}$. Transformacijos idejos autoriais ir didžiausiais propaguotojais buvo amerikiečiai. Jie buvo susirūpinę dèl to, jog jų sajungininkai Europoje vis labiau ir labiau atsilieka kariniu pajégumu srityje, o jei išliks tokie pokyčių tempai, tai labai greitai bet kokios kalbos apie bendrus amerikiečiu ir europiečių karinius veiksmus bus niekinès. Todèl jie pasiūlè pradèti vadinamaji Aljanso transformacijos procesą, kurio pagrindinis tikslas kiek įmanoma labiau priartinti Europos valstybių kariuomenių pajėgumus prie JAV.

Visos transformacijos ašimi ir pagrindiniu katalizatoriumi yra laikomos Greitojo reagavimo pajejgos. Prahos deklaracijoje aiškiai yra suformuluoti reikalavimai, keliami šioms pajėgoms: turinčios pažangias technologijas, lanksčios, lengvai dislokuojamos, mobilios, sugebančios save išlaikyti numatytą laiko tarpą ${ }^{62}$. Amerikiečiai pareikalavo, jog jų Europos sajungininkai savo karines

\footnotetext{
${ }^{59}$ JAV karinè bendruomenè yra labai didelè ir čia visada galima atrasti įvairiu siūlymu, idejų Negalima teigti, jog nèra siūlomi ir kitokie JAV karinių pajègų vystymo planai. Tačiau šios idejjos, nors ir žinomos, netampa dominuojančiomis.

${ }^{60} \mathrm{Tai}$, kad amerikiečių vykdomos karinès reformos sulaukia atgarsio ir kitose valstybėse, galima pailiustruoti paprastu pavyzdžiu. Vienas labiausiai su JAV gynybos sektoriaus transformacija siejamu konceptų yra tinklinės karybos doktrina (ang. network centric warfare). Yra nemažai manančiu, jog ši doktrina yra pagrindinè ašis, apie kurią sukasi visas transformacijos procesas. JAV pavyzdžiu netruko pasekti kitos Vakaru valstybės. Britai turi Network Enabled Capability koncepciją, Śvedija - Network-Based Defense, Australija - Network Enabled Capability/Network Centric Warfare. Panašias doktrinas taip pat kuria olandai, prancūzai.

${ }^{61}$ Prague Summit Declaration, http://www.nato.int/docu/pr/2002/p02-127e.htm, 20070820.

${ }^{62}$ Ten pat.
} 
pajėgas transformuotu pagal ju modeli. Juk norint, kad NATO pajėgos būtų transformuotos, pirmiausia reikia pakeisti, reformuoti nacionalines karines pajègas.

Tačiau NATO transformacija neapsiriboja vien tik struktūros pokyčiais. Keičiama ir karinè mintis, kariniai dokumentai. Panašiai kaip NRF atveju, čia taip pat beveik viskas yra kopijuojama nuo amerikiečiu. Puikus pavyzdys yra NATO tinklinès karybos doktrina (ang. NATO network enabled warfare capabilities) yra amerikietiško varianto kopija (ang. network centric warfare) ${ }^{63}$.

Nors teigiama, kad NRF bus pajejgios atlikti įvairaus tipo misijas, vis dèlto pagrindinis jų uždavinys yra mūšis. Jų uždavinys yra kaip įmanoma greičiau atvykti į krizės vietą, imtis veiksmų ir krizę numalšinti. Visus stabilizavimo darbus turètu atlikti jau kiti NATO daliniai. Tai, kad humanitarinès ir panašaus pobūdžio misijos nėra NRF, puikiai atspindi kilusios diskusijos ir pasipiktinimai dèl jų siuntimo i̇ nuo žemés drebëjimo nukentejjusį Pakistaną.

Dẻl amerikiečių spaudimo Aljanso transformacija, o ypač NRF kūrimas, tapo pagrindiniu NATO darbotvarkẻs klausimu ir galvos skausmu. O tai reiškia, jog Aljanso štabuose ir struktūrose dirbantys civiliai bei kariškiai daugiausia rūpinasi, kaip sukurti karines pajėgas, kurios padètų laimèti mūšsi. Tačiau kaip su pergale kare? Šiuo atveju turbūt būtų galima sakyti, jog NATO yra geresnëje situacijoje nei JAV. Aljanso privalumas yra tas, jog, nepaisant JAV dominavimo ir reikšmès, yra ir kitos valstybès. Tokios valstybès kaip D. Britanija, Vokietija, Prancūzija turi savitas kariavimo tradicijas. Todèl jos gali kritiškiau vertinti JAV karinius pokyčius ir tuo pačiu yra pajėgios pasiūlyti galimus alternatyvius reformos sprendimo būdus. Taip pat politinio NATO lygmens egzistavimas yra nemenkas garantas, jog amerikietiška dvasia pasiekta pergalè kovos lauke bus paversta pergale kare.

NATO koordinuojamą misiją Afganistane, kaip Aljanso transformaciją, taip pat galime vertinti kaip labai teigiamą dalyką. NATO dalyvavimas šioje misijoje leidžia truputị atitraukti valstybių narių dėmesį nuo NRF klausimų. Būtu galima teigti, jog dabar NATO valstybės turi du rūpesčius - NRF formavimą ir misiją Afganistane. NRF Aljansui suteiks pajėgas, galėsiančias laimėti mūši, o Afganistane iggta patirtis leis stabilizuoti situaciją po mūšio.

Toks būtų optimistinis variantas. Tačiau visiems puikiai žinoma, su kokias sunkumais Afganistane susiduria NATO. Ši misija, kartu su NRF, išliks pagrindiniu indikatoriumi, kurie parodys, ar NATO bus pajègi likti efektyviu kariniu aljansu XXI a.

Kalbant apie amerikietiškosios kariavimo tradicijos įtaką NATO raidai, tai susikoncentravimas ties NRF reiškia, jog mažiau dèmesio skiriama pajègumu, galinčiu atlikti kitokio pobūdžio karines misijas, plètrai. O turint omenyje, jog NATO yra didžiulè biurokratinė struktūra, o ji, net ir norèdama, lengvai nepakeis viena kitos politikos. Dar labiau aišku tai, kad amerikiečiu tradicija Aljansą gali paveikti per jo narių karinių pajėgų transformaciją. NATO yra

\footnotetext{
${ }^{63}$ NATO C3 Technical Architecture Volumes, http://194.7.80.153/website/book.asp?menuid=1 $5 \& v s=0 \&$ page $=$ volume1\%2Findex\%2Ehtml, 20070715.
} 
puikus tarpininkas tarp JAV ir kitu Europos valstybių. Aljansas yra ne tik forumas, kuriame valstybės gali apsikeisti žiniomis ir patirtimi, tačiau jis turi ir institucinę bei administracinę galią tiesiogiai ar netiesiogiai priversti valstybes vykdyti vienokią ar kitokią gynybos politiką, plèsti tam tikrus karinius pajègumus. Daugeliu atvejų NATO valstybės savo gynybos reformas vykdo pagal amerikietišką koncepciją. Tai reiškia, jog, jei NATO ir nuspręstų keisti plètojamu pajègumu pobūdi, narès labai apsunkintu šį procesą, nes kariuomenès reforma yra sudètingas ir labai brangus procesas, kuris negali būti pakeistas per vieną naktị.

\section{Amerikietiškos tradicijos atgarsiai Lietuvoje}

Būdama maža valstybe, Lietuva negali sau leisti eksperimentuoti su kariniu pajègu reforma ar plèsti ịvairaus tipo karinius pajėgumus. Turimi finansiniai, o taip pat ir žmogiškieji, resursai to neleidžia daryti. Todèl sprendimas, kokius karinius pajẻgumus vystyti, kuria linkme nukreipti kariniu pajègu reformą, yra labai svarbus. Gal Lietuvai neverta investuoti į ekspedicinių pajëgu kūrimą. Gal užtektų to, jeigu daugiau dèmesio būtų skiriama plètojant ịvairius "nišinius" karinius pajègumus (civilių ir karių bendradarbiavimo, psichologiniu operaciju, žmogiškosios žvalgybos specialistus ir pan.).

Gynybos reforma Lietuvoje igauna pagreitį. Kariuomenės profesionalizacijos klausimas baigiamas išspręsti. Vis daugiau yra kalbama apie transformaciją. Šioje vietoje būtina pabrěžti, jog didesnis susidomëjimas transformacija ir bandymas suprasti tai, kas yra transformacija, atsirado tada, kai to pradèjo reikalauti NATO.

Taigi pasaulyje vyraujančių karybos madų atgarsiai pasiekia ir Lietuvą. Straipsnio įvade buvo minèta, jog Lietuva po nepriklausomybės atkūrimo pradëjo kurti karines pajejgas, kurias Šaltojo karo metu turëjo Vakarų valstybès bei sovietai. Rimtesni pokyčiai Lietuvos gynybos sektoriuje prasidejo 1999-2000, o iggavo pagreiti po rugsẻjo $11 \mathrm{~d}$. išpuoliu bei įstojimo į NATO. Lietuvos kariuomenès transformavimas iš teritorinei gynybai pritaikytos į kolektyvinę gynybą, orientuotą bei galinčią dalyvauti užjūrio misijose, gali būti laikomas vakarietiškos, o ypač amerikietiškos karinès transformacijos įtakos rezultatu. Kariuomenės profesionalizacija, mažinimas, didinamas mobilumas, koncentravimasis ties kokybiniais, ne kiekybiniais aspektais ir kt. - visa tai yra ịrodymai, jog Vakaruose vyraujančios karybos „mados“ yra taikomos ir Lietuvoje. Ir šias madas karyboje diktuoja Jungtinės Valstijos. Būtu galima ginčytis ir diskutuoti dèl to, kiek kitos valstybès prisideda prie visų šiu pokyčiu, bet JAV išlieka galingiausia karine galia pasaulyje. Visi mažiau ar daugiau kopijuoja jos karinio planavimo metodiką ir procedūrą, kariuomenès struktūrą, doktrininius ir taktinius dokumentus, o kas išgali - ir karines technologijas. Tačiau kopijavimas nelygu kopijavimui. Valstybės, turinčios senas karines tradicijas, naujoves modifikuoja, adaptuoja taip, kad jos geriau atitiktu ju propaguojamą 
požiūrị i i karą ir karybą. Kitos gilinasi mažiau ir kopijuoja mechaniškai. Tokiu valstybiu grupei būtų galima priskirti ir Lietuvą. Būdama jauna valstybe Lietuva iki šiol neturi kritiško mastymo tradicijos. Tai jaučiama visose srityse, ne išimtis ir karyba. Kopijuojame, adaptuojame, tačiau nesivarginame klausti, kodèl reikia daryti būtent tai ir pan. Bandymas šalies reikmėms pritaikyti naujausias tendencijas karyboje yra labai sveikintinas dalykas. Tačiau visada reikia nebijoti užduoti klausimus ir bandyti išsiaiškinti, kodèl vyrauja tokios, o ne kitokios tendencijos, mados.

Atsižvelgiant į amerikietišką požiūrị i karybą bei jo įtaką NATO transformacijai, būtų galima sakyti, jog Lietuvos laukia nemaži iššūkiai. Lietuva, reformuodama savo karines pajègas pagal amerikietišką modeli, kuria pajègas, kurios yra orientuotos laimèti kovą, bet ne karą.

Labai supaprastinus, amerikietiškają kariavimo tradiciją būtų galima apibūdinti tokiu išsireiškimu - „šauk, klausimus galèsi užduoti vèliau“ (ang. shot first, ask later). Kadangi amerikiečiai karą laiko kaip alternatyvą bet kokioms diplomatinèms deryboms, tai egzistuoja gana didelè tikimybè, jog jie dažnai gali įsivelti į įvairius karinius konfliktus. Tokią politiką ir tradiciją dèl jos vienpusiškumo būtų galima ta tikra prasme pavadinti „avantiūriška“. Karas Irake gali būti pavadintas didele karine avantiūra, į kurią Vašingtonas akivaizdžiai patraukè, neapsvarstęs visų galimų scenarijų. Kad amerikiečiai turi toki polinki, puikiai savo knygoje iliustruoja jau minètas Bootas. Taigi Lietuvai deklaruojant, jog jos svarbiausias strateginis partneris yra Jungtinės Valstijos, visai naudinga žinoti, kokiomis silpnybėmis pasižymi Vašingtonas. Šios žinios taip pat labai būtų labai naudingos ir su NATO, o dar labiau būtų naudingos politiniuose forumuose.

Kalbant apie karines pajègas, vėl reikia žinoti, jog „avantiūrizmas" gali būti gana pavojingas mūsų kariams, tarnaujantiems kartu su amerikiečiais. Labai tinkamas pavyzdys yra operacija Irake. Amerikiečiai, pradėdami misiją šioje valstybëje, neapskaičiavo daugybės faktoriu, nenumate tolimesniu žingsnių ${ }^{64}$. Prasidèjęs vietinių gyventojų pasipriešinimas buvo labai nemalonus netikètumas amerikiečiams bei valstybėms, kurios buvo atsiuntusios savo karius, tame tarpe ir Lietuvai.

Vertinant tai, kokius karinius pajègumus plètoja Lietuva, akivaizdžiai pastebima, jog labai daug dèmesio skiriama pajègumams, kurie turès dalyvauti konfliktuose, kuriuose bus naudojama „sunaikinimo strategija“. Brigados "Geležinis vilkas" stiprinimas, performavimas, jos logistika bei aprūpinimas - tai kone didžiausias karinių planuotojų rūpestis ${ }^{65}$. Lietuvos specialiosios pajègos

\footnotetext{
${ }^{64}$ Kariškių ir karo ekspertų tarpe tuo metu buvo populiarus anekdotas apie tai, kaip po Bagdado paèmimo D. Rummsfeldas atsisuka į savo generolus ir klausia - „o kas toliau“.

${ }^{65}$ Krašto apsaugos ministro gairès 2008-2013 m.; Krašto apsaugos sistemos plètros programa; Baltoji Lietuvos gynybos politikos knyga, $2006 \mathrm{~m}$.
} 
taip pat yra gana labiau remiamos ir plètojamos ${ }^{66}$. Tačiau ir ju paskirtis yra labiau susijusi su dalyvavimu koviniuose veiksmuose, o ne karinèse misijose, kurios seka po mūšių.

Šiuo metu Lietuvai reikètų pagalvoti, kaip būtų galima subalansuoti karinius pajègumus, ir ieškoti priemonių bei lěšų pajègumams, kurie padètų igyvendinti misijas, kurios būtų jau po konflikto. Atsižvelgiant i galimas ateities grèsmes ir priežastis, dèl kuriu gali kilti konfliktai, akivaizdu, jog pajègumu, galinčių atlikti įvairias stabilizavimo misijas, poreikis didès. Terorizmas, vandens, derlingos žemės trūkumas, didèjanti žmonių migracija tokiuose regionuose kaip Afrika, Artimieji Rytai ir Centrinè Azija didins įtampą tarp valstybiu, įžiebs konfliktus. Ateityje laukia daugybė krizių, kokia šiuo metu yra ištikusi Darfūrą. Labai didelè tikimybė, jog Lietuvai, kaip NATO ir Europos Sajungos narei, teks dalyvauti šiuose ateities konfliktuose. Todèl tai, kad Lietuva, nors ir sunkiai, bet turi savo koordinuojamą Provincijos atkūrimo grupę Afganistane, bus labai naudinga tolimesnei šalies kariniu pajègu plètrai. Patirtis, igyta Afganistane, pravers rengiant karius, kurie greta gebejjimu dalyvauti intensyviuose mūšiuose, mokès vykdyti ginklų kontrolès, valstybès atkūrimo ir panašias misijas.

Tačiau taip pat svarbu pabrèžti, jog ateities krizėms ir konfliktams turi būti pasirengusios ne tik karinès pajègos. Valstybinès institucijos ir politiniai lyderiai turi būti pasirengę išnaudoti pasiekimus karinejje srityje bei paversti juos strategine nauda. Tam reikia ugdyti atitinkamus gebejjimus, stiprinti institucijų bendradarbiavimą bei jų veiklos efektyvumą. Vertinant dabartinę situacija, tikrai nebūtu galima tvirtinti, jog visa tai Lietuvoje egzistuoja ar veikia gerai ${ }^{67}$. Tačiau norint, jog sunkus ir pavojingas šalies karių darbas įvairiose tarptautinėse misijose nenueitų niekais, Lietuva turi išsiugdyti strateginio mąstymo tradiciją. Ji turi gebėti karinį dalyvavimą ir karinio veiksnio naudojimą suprasti ir vertinti plačiau. Priešingu atveju Lietuvos karinę tradiciją taip pat bus galima vadinti "mūšio", bet ne "karo" tradicija.

\footnotetext{
${ }^{66} \mathrm{BNS}$, Lietuvos „„̌aliukai" - Amerikos karinés vadovybès dèmesio centre, $2006 \mathrm{~m}$. gegužès 10 d.; Bačiulis A., Samuolytė V., „Misija Afganistane“, Veidas, 2002 m. rugsẻjo 26 d. nr. 39; BNS, Lietuvos „žaliukai" - patikima reputacija pelnę kariai, teigia JAV generolas, $2006 \mathrm{~m}$. balandžio 29 d.; BNS, Lietuvos Specialiujų operaciju eskadrono misija Afganistane - generaliné repeticija prieš įsiliejima i NATO greitojo reagavimo pajegas, $2004 \mathrm{~m}$. lapkričio $12 \mathrm{~d}$.

${ }^{67}$ Račius E., Maskaliūnaite A., Šlekys D., Urbelis V., Tarptautinés antiteroristinès kovos iššūkiu Lietuvai analizé, Vilnius: Vilniaus universiteto leidykla, 2007.
} 


\section{Išvados}

R. Kaganas kol kas naujausioje JAV užsienio politikos interpretacijoje amerikiečius pavadina „pavojinga tauta“, taip pat įtikinamai parodo, jog JAV visą laiką naudojo agresyvią užsienio politiką, tam labai dažnai pasitelkdama karinę jègą. Ši argumentą dar labiau sustiprina Booto tyrimai. Todèl labai tikètina, jog JAV ir toliau liks „pavojinga valstybe“ bei savo užsienio politiką grịs karine jèga.

Tačiau per istoriją susiformavusi JAV kariavimo tradicija dèl Jomini ideju įtakos, amerikiečiu igimto abejingumo istorijai, jos pamokoms bei kitu priežasčių nulèmė, jog JAV kariavimo tradiciją geriausia vadinti „mūšio“ tradicija. Tai reiškia, jog amerikiečiams karas asocijuojasi su mūšiu, kova. Pergalè mūšyje reiškia pergalę kare. JAV politikų ir kariškių nesugebejimas ar nenoras suprasti, jog karinis susidūrimas ir pergale jame yra tik sudedamoji karo dalis, yra labiausiai nerimą keliantis dalykas. JAV istorija parodè, jog ji tikrai labai dažnai nesugebejjo pergalès mūšio lauke paversti strateginiu laimẻjimu. Tai turbūt yra pati svarbiausia pamoka kitoms valstybėms, o jų tarpe ir Lietuvai. Tiek su NATO, tiek veikiant atskirai su Jungtinėmis Valstijomis, šią Vašingtono silpnybę visada reikia atsiminti.

\section{Literatūros sąrašas}

\section{Oficialūs dokumentai}

1. Baltoji Lietuvos gynybos politikos knyga $2006 \mathrm{~m}$.

2. Krašto apsaugos ministro gairès 2008-2013 m.

3. Krašto apsaugos sistemos plètros programa.

4. NATO C3 Technical Architecture Volumes, http://194.7.80.153/website/ book.asp?menuid=15\&vs=0\&page=volume1\%2Findex\%2Ehtml, 20070715.

5. Prague Summit Declaration, http:/ / www.nato.int/docu/pr/2002/p02-127e. htm, 2007-08-20.

6. US Army, Field Manual FM 3-0, Operations, 2001, http://www.globalsecurity.org/military/library/policy/army/fm/3-0/index.html, 2007-08-25.

7. S. CON. RES. 129, Expressing the sense of Congress regarding the importance and value of education in United States history, June 30, 2000, http:/ /www. goacta.org/publications/Reports/congressres.htm, 2007-10-18.

8. Cheney D., A New American Way of War, speech for Heritage Foundation, May 1, 2003. 


\section{Monografijos ir studijos}

1. Boot M., The Savage Wars of Peace: Small Wars and the Rise of American Power, New York: Basic Books, 2002.

2. Callwell C. E., Small war: a tactical textbook for imperial soldiers,London: Greenhill Books/Lionel Leventhal, 1990.

3. Citino R. M., The German way of war: from the Thirty Years' War to the Third Reich, Lawrence: University Press of Kansas, 2005.

4. Clausewitz C. von, On War. edited and translated by Howard M. and Paret P., Princeton, N. J : Princeton University Press, 1976.

5. Delbrück H., History of the Art of War, vol. 4, vert. Renfroe W. J., Lincoln: University of Nebraska Press, 1990.

6. Echevarria II A. J., Toward an American Way of War. Strategic Studies Institute, U.S. Army War College, 2004, p. 6, http:/ / www.strategicstudiesinstitute. army.mil/pdffiles/PUB374.pdf, 2007-07-10.

7. Edwards S. J. A., Swarming on the Battlefield: Past, Present, and Future.RAND, 2000, http://www.rand.org/pubs/monograph_reports/MR1100/index.html, 2007-08-20.

8. Everts S.,.Freedman L., Grant Ch., Heisbourg F., Keohane D., O’Hanlon M., Eds., European Way of War, London: Centre for European Reform, 2004.

9. French D., The British way in warfare 1688-2000, London: Unwin Hyman, 1990.

10. Gray Ch. H., Postmodern war: the new politics of conflict, London: Routledge, 1997.

11. Gray C. S., War, peace and international relations: an introduction to strategic history, London: Routledge, 2007.

12. Howard M., „,The British Way in Warfare: A Reappraisal“, Howard M., sudar., The causes of wars and other essays, Cambridge, Mass.: Harvard University Press, 1983.

13. Jomini A. H., The art of war, London: Greenhill Books; Pennsylvania: Stackpole Books, 1996.

14. Kagan R., Dangerous Nation: America in the World 1600-1900, New York: Atlantic Books, 2006.

15. Mahan, A. T., The influence of sea power upon history, 1660-1783, London: Sampson Low, Marston \& co, 1890.

16. Martin J. L., Losing America's Memory: Historical Illiteracy in the 21st Century, American Council of Trustees and Alumni, 2000, http:/ / www.goacta.org/publications / reports.html, 2007-10-18.

17. Mead W. R., Special providence: American foreign policy and how it changed the world, New York: Knopf, 2001.

18. Owens W. A., Offley E., Lifting the Fog of War, Baltimore: The Johns Hopkins University Press, 2001.

19. Račius E., Maskaliūnaitė A., Šlekys D., Urbelis V., Tarptautinés antiteroristinès kovos iššūkiu Lietuvai analizé, Vilnius: Vilniaus universiteto leidykla, 2007. 
20. Roosevelt T., Theodore Roosevelt: an autobiography, New York: Da Capo, 1985.

21. Scales R. H., Jr., Yellow smoke: the future of land warfare for America's military, Lanham, Md.; Oxford: Rowman \& Littlefield Publishers, 2003.

22. Small Wars Manual, United States Marine Corps, 1940, http:/ /www.au.af. $\mathrm{mil} / \mathrm{au} / \mathrm{awc} / \mathrm{awcgate} / \mathrm{swm} /$ index.htm, 2007-10-15.

23. Stern Sh. M., Effective State Standards for U.S. History: A 2003 Report Card, Thomas B. Fordham Institute, 2003 September, http:/ /www.fordhaminstitute. org/institute/publication/publication.cfm?id=320, 2007-10-18.

24. Summers H. G., On strategy: a critical analysis of the Vietnam War,New York: Dell, 1984.

25. Weigley, R. F., The American way of war: a history of United States military strategy and policy, New York: Macmillan, 1973.

\section{Akademiniai straipsniai}

1. Adam T.K, „Future Warfare and the Decline of Human Decision making". Parameters. Winter 2001-02, 61, http:/ / carlisle-www.army.mil/usawc/ Parameters/01winter/adams.htm 04102007.

2. Boot M., „The New American Way of War" "Foreign Affairs Vol. 82, No. 4, July/August 2003.

3. Strachan H., „The British Way in Warfare“, Chandler D., sudar., The Oxford history of the British Army, Oxford: Oxford University Press, 1996.

4. Cassidy R. M., „The British Army and Counterinsurgency: The Salience of Military Culture", Military review. May -June 2005.

5. Cebrowski A. K., Barnett T. P. M., „The American Way of War", Transformation Trends, January 13, 2003.

6. Cebrowski A. K., and Garstka J., „Network-Centric Warfare: Its Origin and Future", Naval Institute Proceedings Magazine, 1998, January, http:/ / www. usni.org/Proceedings / Articles98/PROcebrowski.htm, 2007-07-10.

7. Craig G. A., „Delbrück: The Military Historian“, Paret P., sudar, Makers of modern strategy from Machiavelli to the nuclear age, Oxford: Clarendon, 1984.

8. Graham S., „America's robot army“. New Statesman, Monday 12th June 2006.

9. Gray C. S., „Strategy ins the nuclear age: The United States, 1945-1991“, Murray W., Knox M., Bernstein A., sudar, The making of strategy: rulers, states, and war, Cambridge: Cambridge University Press, 1994.

10. Linn B. M., "The American Way of War Revisited“ with a response by Russell F. Weigley, The Journal of Military History 66, April 2002.

11. Mead W. R., „God's country?“, Foreign Afairs, September/October 2006.

12. Murray W., ",Clausewitz out, computer in: Military Culture and Technological Hubris", The National Interest. June 01, 1997. 
13. Murray W., „,Thinking About Revolutions in Military Affairs“, Joint Force $Q u$ arterly, 16, Summer 1997, 69-76, http://www.dtic.mil/doctrine/jel/jfq_pubs / 1416pgs.pdf, 2007-08-28.

14. Powell C. L., „U.S. Forces: Challenges Ahead“, Foreign Affairs. 1992 Winter.

15. Sinnreich R. H., ,Awkward partners: military history and American education", cited from Murray W. and Sinnreich R. H., sudar., The past as prologue: the importance of history to the military profession, Cambridge: Cambridge University Press, 2006.

16. Van Riper P. K., „The relevance of history to the military profession: an American Marine's view", cited from Murray W. ir Sinnreich R. H., sudar., The past as prologue: the importance of history to the military profession, Cambridge: Cambridge University Press, 2006.

17. Watts B. D., Clausewitzian Friction and Future War, Washington: Institute for National Strategic Studies of National Defense University, 2000, 23, http:/ / www.clausewitz.com/CWZHOME/Watts2/FrictionTOC.htm, 2007-10-13.

\section{Periodika, agentūrų pranešimai}

1. Bačiulis A., Samuolytė V., „Misija Afganistane“, Veidas, 2002 m. rugsëjo 26 d. nr. 39.

2. BNS, Lietuvos „žaliukai“ - Amerikos karinés vadovybès dèmesio centre, $2006 \mathrm{~m}$. gegužès $10 \mathrm{~d}$.

3. BNS, Lietuvos „žaliukai“ - patikima reputacija pelnę kariai, teigia JAV generolas, $2006 \mathrm{~m}$. balandžio $29 \mathrm{~d}$.

4. BNS, Lietuvos Specialiuju operaciju eskadrono misija Afganistane - generalinè repeticija prieš isiliejima i NATO greitojo reagavimo pajegas, $2004 \mathrm{~m}$. lapkričio $12 \mathrm{~d}$. 